\title{
THE MARRIAGE OF RICHARD BASSET: AN UNDETECTED FORGERY IN THE NAME OF HENRY I*
}

Among the many surviving acts of Henry I, king of England from 1100 to 1135, few are of greater interest than the remarkable charter allowing the marriage of Richard Basset to Matilda Ridel. Its significance was first realized by Frank Stenton, who printed the Latin text, with a translation, in his book The First Century of English Feudalism 1066-1166 (1932). The importance of the act was further emphasised by its inclusion in Douglas and Greenaway’s English Historical Documents ii 1042-1189 (London, 1953), which brought it to wider attention. Only Henry's act concerning the marriage of Sybil, daughter of Bernard de Neufmarché, to Miles of Gloucester, which survives as an original in the National Archives, is of comparable significance for our understanding of Henry I's role in consenting to or arranging the marriages of his tenants-in-chief. ${ }^{1}$

By this writ, which is of apparent date January $1121 \times 10$ June $1123,{ }^{2}$ King Henry gave an unnamed daughter of Geoffrey Ridel to Richard Basset, with custody of Geoffrey's lands, to hold until Robert Ridel was able to become a knight and marry a daughter of a daughter of Ralph Basset. We know that Ralph Basset was Richard's father, so Robert was to marry one of Richard Basset's nieces; we deduce that Robert Ridel was Geoffrey Ridel's underage son. When Robert Ridel gained his father's lands, Richard Basset was to have $£ 20$ land and four enfeoffed knights of the king's demesne as a form of compensation. The writ goes on to specify what was to happen if Robert Ridel were to die without an heir of his body. In that case, Richard Basset was to have all of Geoffrey's lands, of whomsoever they were held. Then follows a list of eighteen men and one woman at whose request and with whose advice the king had made the gift and agreement. The writ, printed in translation below and in Latin in the Appendix, is known from a single medieval source, the 'Basset of Weldon cartulary', compiled for Ralph Basset of Weldon. The cartulary's first scribe, working probably in $1236 \times 1241$, entered fifty-two documents including the writ for Richard Basset. Other documents were added later. ${ }^{3}$

Henry king of the English to the bishop of Lincoln and Earl David and the earl of Leicester and Earl Ranulf of Chester and all barons and lords of whom Geoffrey Ridel held lands and all sheriffs in whose officialdoms he held them greeting. Know that I have given a daughter of Geoffrey Ridel to

* I owe thanks to Professor Richard Sharpe, of the History Faculty, University of Oxford, who first introduced me to the charters of William II and Henry I, and who was kind enough to give this paper a close reading. I am also grateful to Professor Nicholas Vincent, of the University of East Anglia, who allowed me pre-publication access to his forthcoming edition of the charters of Henry II.

${ }^{1}$ For the Gloucester/Neufmarché charter, see Regesta regum Anglo-Normannorum, 1066-1154, ed. H. W. C. Davis, R. J. Whitwell, C. Johnson, H. A. Cronne \& R. H. C. Davis, 4 vols (1913-69), ii. 162 (no. 1280); printed Ancient Charters Royal and Private Prior to 1200, ed. J. H. Round, Pipe Roll Society, x (1888), 8-10, (no. 6).

${ }^{2}$ After the death of Geoffrey Ridel, so after the sinking of the White Ship and the king's resumption of business early in 1121, and before the king left for Normandy on 10 June 1123 for the last time before his brother-in-law Earl David, one of the addressees of the writ, became king of Scotland (Symeonis monachi opera omnia, ed. T. Arnold, 2 vols, Rolls Series 75 (1882-5), ii. 273).

3 The roll was edited at Basset Charters c. 1120 to 1250, ed. W. T. Reedy, Pipe Roll Society, NS l (1995), 1-42 (nos. 1-78). 
Richard Basset in marriage and the custody of the land of the said Geoffrey Ridel until Robert Ridel shall be able to be a knight and take in marriage a granddaughter of Ralph Basset, namely a daughter of a certain daughter of his (Ralph's) by his wife. And then the foresaid Richard shall have $£ 20$ of land with his wife in dowry of my fee in demesne and four enfeoffed knights. And if Robert should die without heir of his wife I grant to Richard Basset and his heir whom he will have had of the daughter of the foresaid Geoffrey the whole land of Geoffrey Ridel of whomsoever he held it. And if the daughters of Geoffrey Ridel during the lifetime of Robert their brother or during the custody of Richard Basset shall not be married, Richard Basset shall provide for them with my counsel and at my discretion. And this gift and agreement were made at the request of and with the counsel of Earl Ranulf of Chester and William his brother and Nigel d'Aubigny and other of their relatives and Geva their mother and Geoffrey the chancellor of Earl Ranulf of Chester and Simon the dean of Lincoln and William fitz Ranulf and Thomas de Saint-Jean and Geoffrey de Clinton and Pain fitz John and William d'Aubigny and Humfrey de Bohun and Robert Musard and Robert Basset and Osmund Basset and Thurstan Basset and William the constable of Earl Ranulf of Chester and Ralph fitz Norman and Hugh Malbank. At Woodstock.

The circumstances leading to the production of the writ are well known. Geoffrey Ridel, one of Henry's most prominent justices, had died in the wreck of the White Ship on 25 November 1120, alongside many others including the king's own son, William Ætheling. ${ }^{4}$ As the writ makes clear, Geoffrey had held lands of several lords. The lands Geoffrey held of the king were substantial, and included much of the Domesday fee of Robert de Bucy, a major landowner in Leicestershire and Northamptonshire. The location of the lands is reflected in the men to whom the writ was addressed: the bishop of Lincoln, whose enormous diocese included Leicestershire and Northamptonshire, David, earl of Huntingdon and (probably) Northampton, and the earl of Leicester. Geoffrey's widow Geva, named as one of those who gave counsel, held lands of the final addressee, Earl Ranulf of Chester, who had inherited the earldom from his cousin Richard, another casualty of the White Ship disaster. Geva was an illegitimate daughter of Richard's father Earl Hugh, who had died in 1101. ${ }^{5}$ Richard Basset went on to become a prominent justice: his father Ralph Basset was still active as a justice at the apparent date of the writ. Richard and his wife Matilda were to found Launde priory in Leicestershire $c .1125$. Much of the foundation endowment, including the site of the priory, lay within the fee that Robert de Bucy had held in 1086, which the couple gained under the terms of this act.

\footnotetext{
${ }^{4}$ There are several accounts of Geoffrey Ridel and of Ralph and Richard Basset. J. H. Round wrote short articles on each of them for the $D N B$. The $O D N B$ has new entries by J. A. Green. The careers and landholdings of Richard Basset and his father Ralph were discussed by William Reedy in 'The first two Bassets of WeldonNovi barones of the early and mid-twelfth century', Northamptonshire Past and Present, iv (1969-70), 241-5, 295-8. Reedy wrote more widely on the family in the introduction to Basset Charters, which includes much on Ralph and Richard at pp. viii-xii, xxviii-xxx, xxxii. J. A. Green, Government of England under Henry I (Cambridge, 1986), pp. 145-6, 231-2, discusses the fees held by Ralph and Richard Basset, and in 'Women and inheritance in Norman England: The case of Geva Ridel', Prosopon Newsletter, xii (2001), 1-9, speculates as to the identity and inheritance of Geva Ridel. For Launde priory, see VCH Leics, ii. 10-13.

${ }^{5}$ The question of Geva's legitimacy has been discussed by several scholars. It is hard to accept G. Wrottesley's suggestion, made in his 'Basset charters', Collections for a History of Staffordshire 3 (1882), 187-94, at pp. 187-8), and repeated by Reedy, Basset Charters, p. xii, that she was the lawful heir of Earl Hugh, who was not allowed to succeed to the earldom, but received the Bucy fee in compensation. It is tolerably certain that Geva was illegitimate and that she never held the fee of Robert de Bucy in her own right: I hope to lay out the evidence in another paper.
} 
Henry I's coronation charter provided that 'if, when my baron or another man has died, his daughter shall have remained as heir, I shall give her and her land by the counsel of my barons'. ${ }^{6}$ Here, apparently, we see that clause in action, though Matilda Ridel was not yet her father's heir. Not many years can have gone by before the events anticipated in the writ came to pass. Nothing more is heard of Robert Ridel, so we may assume he died before he was able to succeed to his father's lands. An entry in the first surviving pipe roll shows that Richard Basset had the Ridel lands in his custody in 1130. After Richard and Matilda had died the fee, which came to be known as the honour of Great Weldon, can be seen in the hands of their sons Geoffrey II Ridel and Ralph II Basset.

The writ was of unusual interest, Stenton wrote, because of 'the rarity of documents which illustrate in any detail the king's behaviour as the supreme feudal lord'. He noticed in particular 'the significance of knighthood as a sign that a military tenant has come of age ... and the care with which members of the higher baronage regarded the interests of those connected with them by family relationship'. For Stenton the most interesting feature of the charter was the composition of the body giving counsel to the king, which included representatives of 'the feudalism of the Conqueror's day' in conjunction with 'the new baronage which had risen into importance since the accession of William II’.

Forgery is extremely common in Anglo-Norman royal charters, but is often difficult to detect. Several techniques may be put to use, but all have limitations. If there is a surviving original, expert examination may reveal that the script is later than the document's apparent date, or that the seal is from a forged matrix. Some forgeries are exposed by chronological impossibilities among the witnesses or addressees. Such cases are comparatively few, for most forgers were careful to take their names from an authentic document. When chronological difficulties do arise, editors have sometimes been tempted to ignore the difficulty, postulating a slip by the original scribe or an error in copying. Occasionally a charter has phrasing which seems to belong to a later period, but this may result from pioneering or eccentric drafting, or interpolation by a later copyist. A fundamental question that ought to be considered before accepting a charter as authentic is often overlooked. We must ask whether it is plausible that the king would seal such an act in the circumstances of the time, or whether it is more likely that the act was produced in different circumstances at a later date.

Henry's charter for Richard Basset does not survive in the original, so it is not possible to check its physical characteristics. There are no serious difficulties in chronology or phrasing. It is only when we try to understand the act from the viewpoint of the king himself that doubts about its authenticity arise. The sinking of the White Ship in November 1121 presented Henry I with several challenges besides the gravest of them all, the death of his only legitimate son. A number of tenants-in-chief had been lost, and arrangements had to be made for their replacement. What was to be done about Geoffrey Ridel, who had held the Bucy fee in chief, and who on the evidence of this act had left an underage son Robert and

\footnotetext{
${ }^{6}$ Regesta, ii. 1 (no. 488); printed Die Gesetze der Angelsachsen, ed. F. Liebermann, 3 vols (1903-16), i. 521 [3].
} 
two or more daughters? The king must first appoint a trustworthy custodian to hold Geoffrey's lands until his son came of age. Ralph Basset would have been a satisfactory candidate in 1120, but perhaps not his son Richard, who appears in the king's company only from $c$. 1125. A suitable marriage would be needed for the heir. Of less pressing importance were the marriages of Geoffrey's daughters and the remarriage of his widow Geva. The king might either arrange the marriage of the heir, or delay a decision for the time being, placing him in the keeping of a suitable baron. Thus we might expect to see a grant of the custody of the lands during the minority to a trusted officer, perhaps with the marriages of Geoffrey's daughters, and even, perhaps, with the marriage of the heir. In that case, however, the marriage of the heir would have been the central and most important element of the grant. Instead, the focus here is on the custody of the lands of Geoffrey Ridel and the marriage of one of his daughters. The heir Robert was to be married off to some nondescript granddaughter of Ralph Basset. There is significant and unexpected detail as to what was to happen if Robert died. Detailed provisions of this type, dealing with hypothetical future circumstances, are entirely unprecedented in authentic royal charters at this date. The act cannot be reconciled with the king's priorities in the early 1120s, but it exactly satisfies the needs of Richard Basset and his descendants after the death of Robert Ridel. It is hard to avoid the conclusion that it was produced after the heir's death. There is another indication of the circumstances prevailing at the time of production. The king's provisional grant was to 'Richard Basset and his heir', rather than the more usual 'Richard Basset and his heirs', suggesting that the draftsman was thinking of Richard's son and heir Geoffrey II Ridel, a product of the marriage allowed by the charter and as yet unborn at the apparent date. ${ }^{7}$

Other suspicious details emerge when we reexamine the writ from a more sceptical viewpoint. The compensation of $£ 20$ land and four knights’ fees that Richard was to receive at the end of his guardianship, when the heir became a knight, is highly unlikely. Why would the king compensate Basset if his custody of the Ridel fee proved temporary? That was the normal outcome when the custody of lands was given to royal officers. And if the king had wished to give such compensation, surely it would have come from the fee that had belonged to Geoffrey Ridel, not from the king's own land.

The list of nineteen people from whom the king sought counsel also arouses suspicion. That the first three were kinsmen of the children of Geoffrey Ridel is implied by the phrase which follows: 'et aliorum parentum suorum et Geue matris sue' ('and other of their kinsmen and Geva their mother'). Earl Ranulf and his brother William Meschin were cousins to Geva Ridel. Nigel d'Aubigny had been married to Maud de l'Aigle, daughter of Richer de l'Aigle, by Judith, sister of Earl Hugh. Thus Maud was first cousin to Earl Ranulf and Geva Ridel, and so Nigel was an in-law of the earls of Chester. But Nigel had repudiated Maud, apparently in June 1118, and certainly before the apparent date of the writ. ${ }^{8}$ Next in the list is Geoffrey, said to be chancellor of the earl, an office not otherwise known to exist until Ranulf III became earl in the late twelfth century. ${ }^{9}$ Then comes Simon Bloet, dean of

\footnotetext{
${ }^{7}$ The phrase 'his heir' (heredi suo) appears in the surviving charters of Henry I only here: 'his heirs' (heredibus suis) is used in more than 25 acts.

${ }^{8}$ Complete Peerage, ix. 369.

${ }^{9}$ D. Crouch, 'The administration of the Norman earldom', The Earldom of Chester and its Charters (Chester, 1991), pp. 69-95, at 86-7.
} 
Lincoln, a son of Bishop Bloet; then William fitz Ranulf, who otherwise occurs in Henry's acts only in a spurious confirmation to Huntingdon priory, in which he appears as both witness and donor of land. ${ }^{10}$ The benefactor of Huntingdon, though, was William Meschin, brother of Earl Richard, who has already appeared in the list. The next five names, Thomas de Saint-Jean, Geoffrey de Clinton, Pain fitz John, and Humfrey de Bohun were all frequent witnesses to the king's acts. Robert Musard does not otherwise appear in royal acts until the reign of Stephen. Next are three members of the Basset family. Robert Basset was presumably the man named in the Northamptonshire survey as a tenant of the honour of Wallingford in Thenford and of William d'Aubigny in Rushton. ${ }^{11}$ Osmund Basset may have been the tenant of 11/4 knights' fees of the honour of Wallingford in $1166 .{ }^{12}$ Thurstan was a son of Ralph I Basset, perhaps to be identified with the Thurstan Basset who held 6 knights' fees and two parts of a fee of the honour of Wallingford in $1166 .{ }^{13}$ The final three men were all associated with the earldom of Chester. William fitz Nigel was the well-known constable of the honour of Chester. Ralph fitz Norman was brother of Hugh fitz Norman: the pair were among the earliest benefactors of St Werburgh's abbey in Chester. ${ }^{14}$ Hugh Malbank, the founder of Combermere abbey, appears to have held Alstonefield (Staffs) of the honour of Chester. ${ }^{15}$

The list is dominated by the earl of Chester, his kinsmen and tenants. We may doubt that the king would consider the marriage of Matilda Ridel to be a matter to be decided by the earl and his circle. Rather, this appears to be a string of names confected from at least two sources, most likely comprising a charter of Henry I and another of Ranulf earl of Chester, combined with some personal knowlege of the Basset family and its connections.

Two other documents in the Basset archive have preserved similar lists of names. The first of these is a supposed gift by Robert de Tosny to Robert de Bucy, of land in Madeley Holme (Staffs) as one knight's fee. ${ }^{16}$ The grantor is apparently intended for the Domesday tenant of Madeley, Robert of Stafford, who was a younger son of Roger de Tosny and died $c$. $1088,{ }^{17}$ but the witnesses imply a date in the 1120 s. These are given as 'Hiis testibus, Nigello de Aubeney, Rannulfo comite Cestrie, Galfrido cancellario, Simon(e) decano Lincoln', Willelmo filio Reg', Thoma de sancto Iohanne, Willelmo de Aubeney Britone, Wnfrido de Bohun et aliis'. All are included in the list of those who gave counsel, if we allow Willelmo filio Reg' to be a mistake for Willelmo filio Ran'. Here we see Geoffrey the chancellor in a different context: although his name follows that of the earl of Chester, it is likely that Geoffrey Rufus, king's chancellor from 1123 until May 1133, was intended. ${ }^{18}$ Apart from the

\footnotetext{
${ }^{10}$ Regesta, ii. 198 (no. 1449).

${ }^{11}$ VCH Northants, i. 368b, 385a.

${ }^{12}$ Red Book of the Exchequer, ed. H. Hall, 3 vols, Rolls Series 99 (1896), p. 309.

${ }^{13}$ Historia ecclesiae Abbendonensis. The History of the Church of Abingdon (Oxford, 2002-7), ed. J. G. H. Hudson, ii. 250-51 (§ 251); Hall, Red Book, p. 309.

${ }^{14}$ The Charters of the Anglo-Norman Earls of Chester c. 1071-1237, ed. G. Barraclough, Record Society of Lancashire and Cheshire, cxxvi (1988), 5, 14, 41 (nos. 3, 8, 28).

${ }^{15}$ Monasticon Anglicanum, rev. edn, ed. J. Caley, H. Ellis and B. Bandinel, 6 vols in 8 (1817-30), v. 323 (no. i); W. Farrer, Honors and Knights' Fees, 3 vols (1923-1925), ii. 261.

${ }^{16}$ Reedy, Basset Charters, pp. 4-5, no. 10.

${ }^{17}$ Complete Peerage, xii/1. 168.

${ }^{18}$ Regesta, vol. ii, pp. ix-x.
} 
chronological difficulties and the undue precedence given to Nigel d'Aubigny, the advanced form of this deed, which includes a warranty clause more appropriate to the late twelfth or thirteenth century, leaves us in no doubt that it is a forgery. It appears to have been produced to reinforce and clarify an authentic deed of later date which shares some of its phrasing. ${ }^{19}$

The other list of names is contained in a note of a deed added to the bottom of the Basset extracts from the Leicestershire survey. That deed also appears to have been a forgery, and a poor one, for the references to donor and beneficiary are very confused: 'Hec sunt nomina testium de dono quod comes Hugo Cestrie pater comitis Ranulfi dedit Ric(ardo) Basset in dotem cum Geua sorore sua, scilicet in Draitonam et in Tamworthe cum pertinenciis: Nigellus de Albeigny, Will(elmus) filius Ranulfi, Thomas de sancto Iohanne, Paganus filius Iohannis, Will(elmus) de Albeney Brito, [[H]]unfridus de Bohun, Rob(ertus) Musard, Rob(ertus) Basset, Osmundus Basset, Turstanus Basset, Will(elmus) constabularius $\left[\left[* * *\right.\right.$ Cest]]rie, Rad(ulfus) filius Normanni, Hugo Maubanc' ${ }^{20}$ Again, all are included in the list of those who gave counsel. The exact relationship between the three lists of names is impossible to ascertain, but it is clear that the Basset archive contained collections of names of plausible witnesses to charters of the early twelfth century, and that these were used to add credibility to forged documents.

We have, therefore, several reasons to mark this act as a forgery. Most importantly, it does not accord with the king's priorities in the early 1120s; rather, it represents the needs of Richard Basset or his heirs at a later date. The provision for hypothetical future events is unparalleled, and it includes an unlikely compensation at the conclusion of the wardship. The list of those who gave counsel is implausible, and contains three errors: the inclusion of Nigel d'Aubigny, the two occurrences of the earl's brother William, and the placing of Geoffrey as chancellor of Earl Richard rather than the king. We must therefore conclude that the act was fabricated some time after the death of Robert Ridel, to promote the claim of Richard Basset's wife Matilda Ridel to be the sole heir of her father Geoffrey Ridel. It may have been drawn up for Geoffrey II Ridel after his father's death, to assist in obtaining the Empress's confirmation given in $1144 .{ }^{21}$ Alternatively it may have been produced soon after the accession of Henry II, or perhaps later, to defend against the claims of coheirs. There are no entries in the pipe rolls that point towards such claims, however, and the sisters of Matilda Ridel mentioned in this act remain obscure. ${ }^{22}$

\footnotetext{
${ }^{19}$ Reedy, Basset Charters, p. 6 (no. 12).

${ }^{20}$ British Library, Sloane Roll xxxi. 7, rot. 10r.

${ }^{21}$ Printed Regesta, iii. 15 (no. 43).

${ }^{22}$ Mabel Ridel was perhaps one of them. A thirteenth-century addition to the Peterborough 'Descriptio Militum', which gives a descent from Anketil de Saint-Medard, states that Richard, Anketil's son and heir, had Geoffrey de Saint-Medard and Hugh Ridel of Mabel Ridel (E. King, 'The Peterborough 'Descriptio Militum' (Henry I)', EHR, lxxxiv (1969), 84-104, at p. 97, n. 3). William Fleming rendered account of 32 marks for Mabel, wife (i.e. widow) of Richard de Saint-Medard cum dote sua in the Northamptonshire account of 1129-30 (Magnum rotulum scaccarii, vel magnum rotulum pipae, de anno tricesimo-primo regni Henrici primi . . . , ed. J. Hunter (1833, repr. 1929), pp. 83-4). It was probably the same Hugh Ridel who held one knight's fee of new feoffment of Geoffrey II Ridel in 1166 (Hall, Red Book, p. 331). On the evidence of a charter by which Henry II confirmed the gift of land in Exning (Suff) by Geoffrey Ridel, archdeacon of Canturbury, to Richard de L'Isle and his wife Galiena, the archdeacon's cognata and daughter of William Blund ad se maritandum (no. 1347 in
} 
Although it can be deduced that Robert Ridel did die without heirs of his body, thereby permitting Richard Basset to claim the Ridel honour of Great Weldon, it is not clear when his death occurred. The foundation of Launde priory by Richard Basset and Matilda Ridel on land at Loddington that had been in the Bucy fee at the time of the Domesday Survey would appear to indicate the latest possible date, and it seems the priory was in existence by 1125. The pipe roll for the year to Michaelmas 1130, however, includes Richard Basset’s account for $£ 40$ 'pro custodia terre Gaufridi Ridelli', ${ }^{23}$ rather than 'pro terra Gaufridi Ridelli' as might be expected had he by then acquired the lands in perpetuity. As has been seen, the address of the forgery is exactly what we might expect in a charter granting the lands of Geoffrey Ridel. This suggests that there was an authentic act granting the Ridel lands among the documents from which the false charter was confected, probably in favour of Ralph rather than Richard Basset. We do not know what the king wished to give to Ralph or Richard Basset. Was it just custody of the lands during the minority of Robert Ridel? Or did he really intend the Bucy fee to pass to a descendant of Ralph Basset?

The writ for Richard Basset reminds us that English deeds and charters apparently produced in the first half of the twelfth century must be approached with scepticism. Detailed analysis of palaeography, sigillography, diplomatic, and prosopography are essential if forgery is to be detected, but we must also consider the simple questions 'is it plausible?' and 'cui bono?'.

\section{APPENDIX}

1 Purported charter granting Geoffrey Ridel's daughter to Richard Basset in marriage, with the custody of Geoffrey's lands

CARTULARY COPY: Basset cartulary, British Library, Sloane Roll xxxi. 4, mem. 5r (no. 47) (1236 × 1241) ('carta [[***]]', red rubric ink faded and illegible) [B]; ibid. mem. 3a, recto (no. 26), in copy of proceedings of 1383 (abbreviated, s. xiv/xv) (Reedy, Basset Charters, p. 15, no. 26).

PRINTED: F. M. Stenton, The First Century of English Feudalism, 1066-1166 (Oxford, 1932), 258-9 (no. 4); ibid. 34 (in English) [from B]; repr. 2nd edn (Oxford, 1961), 259-60 (no. 4); ibid. 35; English Historical Documents ii 1042-1189, ed. D. C. Douglas \& G. W. Greenaway, (London, 1953), 922-3 (no. 245) (in English) [from Stenton], repr. 2nd edn (London, 21981), 988 (no. 245); Reedy, Basset Charters, 24 (no. 47) [from B]. CALENDAR: Farrer 494; Regesta 1389.

H(enricus) rex Angl(orum) episcopo Lincol(niensi) et comiti Dauid' et comiti de Legrec(estria) et comiti Ranulfo de Cestria et omnibus baronibus et dominis de quibus Galfrid(us) Ridel terras tenebat et omnibus uicecomitibus in quorum ministeriis eas tenebat salutem. Sciatis me dedisse Ric(ardo) Basset filiam Galfr(idi) Ridel in uxorem et custodiam terre predicti G(alfridi) Ridel donec Rob(ertus) Ridel possit esse miles et ducat in uxorem neptem Rad(ulfi) Basset, scilicet filiam cuiusdam filie sue de muliere. Et tunc habeat

N. C. Vincent's forthcoming edition), K. S. B. Keats-Rohan, Domesday People (Woodbridge, 1993), pp. 23031, postulated that William Blund's unnamed wife was another daughter.

${ }^{23}$ Hunter, Magnum rotulum scaccarii, p. 81. 
predictus Ric(ardus) XX libratas terre cum uxore sua in maritag(io) de feodo meo in dominio et IIII milites feodatos. Et si Rob(ertus) morietur sine herede de muliere concedo Ric(ardo) Basset et heredi suo quem habuerit de filia predicti Galf(ridi) totam terram Galf(ridi) Ridel de quocumque tenuisset. Et si filie Gal(fridi) Ridel in uita Rob(erti) fratris sui uel in Ric(ardi) Basset custodia maritate non fuerint, Ric(ardus) Basset eas consulet consilio meo et consideracione mea. Et hec donacio et conuencio facte sunt requisicione et consilio comitis Ran(nulfi) de Cestria et Willelmi fratris sui et Nigell(i) de Alban(ni) et aliorum parentum suorum et Geue matris sue et Gal(fridi) cancellarii comitis Ran(nulfi) de Cestra et Simon(is) decani Lincol(niensis) et Willelmi filii Ran(nulfi) et Thome de sancto Ioh(anne) et G(alfridi) de Clinton' et Pagan(i) filii Ioh(annis) et Wil(lelmi) de Auben(ni) et Wnfr(idi) de Bowhun et Rob(erti) Musard et Rob(erti) Basset et Osmund(i) Basset et Turstin(i) Basset et Will(elmi) constabularii comitis Ran(nulfi) de Cestra et Rad(ulfi) filii Norm(anni) et Hug(onis) Maubaunc. Apud Wodestoke. 